\title{
Development of Green Banana (Musa paradisiaca) as Potential Food Packaging Films and Coatings
}

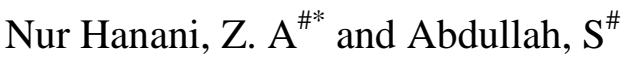 \\ \# Department of Food Technology, Faculty of Food Science and Technology, Universiti Putra Malaysia, 43400, Selangor, Malaysia \\ E-mail: Hanani@upm.edu.my; syarinaa@yahoo.com
}

* Halal Products Research Institute, Universiti Putra Malaysia, 43000 UPM Serdang, Selangor, Malaysia.

\begin{abstract}
The aim of this study was to develop biodegradable packaging films based on a unripe green banana (Musa paradisiaca L.) with different plasticizers; glycerol, polyethylene glycol (PEG) and sorbitol at various concentrations (10-50\%). Banana films were produced by using casting method and physical properties of these films were determined. Banana films with $10 \%$ of PEG showed the lowest water solubility $(\mathbf{P} \leq \mathbf{0 . 0 5})$ followed by films with glycerol and sorbitol. Banana films with $40 \%$ plasticizers possessed the lowest water vapour permeability (WVP) whereas films with $30 \%$ glycerol exhibited higher values of tensile strength $(P \leq 0.05)$ compared to films with PEG and sorbitol. However, types of plasticizers did not influence the thickness of the films. Also, used of higher concentrations of plasticizers had increased the solubility values. These findings reveal that concentrations and types of plasticizers have significant roles to provide banana film or coating with good physical properties.
\end{abstract}

Keywords - Banana; Biodegradable films; Packaging

\section{INTRODUCTION}

Banana (Musa paradisiaca) is a climacteric fruit and grown in many tropical countries such as Malaysia, Indonesia and Thailand for the purpose of raw consumption, processed food, making fibre, etc. This fruit is a good source of potassium, dietary fibre and minerals. However, losses of banana production are very high due to their perishable nature, inadequate post-harvest handling and enzymatic browning effect. Therefore, this fruit has poor storage characteristics since it presents high respiratory rate after harvest and ethylene production that make it highly perishable and prone to postharvest losses [1].

The losses of this fruit can be reduced by processing of surplus banana and those unsuitable for fresh consumption [2]. During unripe stage, Musa paradisiaca species has high starch content compared to different varieties of banana. Therefore, the processing of unripe banana into flour and starch is useful as a possible resource for food and other industrials applications.

As banana mainly consists of starch and pectin [3], these compounds may also provide sufficient properties to form renewable, biodegradable and low cost films and packages [4]. Furthermore, the polysaccharides in banana powder give extra hydrogen bonding contacts between polymers chains which responsible for the film-forming capacity.
The objective of this study was to develop biodegradable films based on unripe green banana by incorporating different types and concentrations of plasticizers.

\section{MATERIALS AND METHOD}

\section{A. Materials}

The raw of green bananas cv. Musa paradisiacal or also known as "Pisang Berangan" in Malaysia was purchased from Pasar Borong Serdang, Selangor, Malaysia. The fresh and green colour of banana was selected to produce banana flour and further film formation. Food grade glycerol, sorbitol and polyethylene glycol (PEG) were purchased from the Fisher Scientific (Leicestershire, UK).

\section{B. Methods}

\section{1) Films preparation}

Banana films were manufactured by casting method. Banana powder with $6 \%(\mathrm{w} / \mathrm{w})$ was mixed with distilled water and stirred at $80^{\circ} \mathrm{C}$. Plasticizers (glycerol, sorbitol and PEG) were added to the solution, respectively with the concentration of 10 to $50 \%$. Films manufactured were peeled and stored at temperature $23 \pm 2{ }^{\circ} \mathrm{C}$ and relative humidity (RH) $50 \pm 5 \%$ before further analysis. 


\section{2) Film testing}

\section{3) Film thickness}

The film thickness was measured with a hand-held micrometer Dial Thickness Gage (No.7301, Mitutoyo Corporation, Tokyo, Japan) to the nearest $0.01 \mathrm{~mm}$.

\section{4) Color properties}

The color of the films produced was measured by using Colorimeter Minolta Chroma Meter CR-300 (Minolta, Japan). The results were expressed in accordance with the CIELAB color space system.

\section{5) Mechanical properties}

Tensile strength (TS), Young's modulus (YM) and elongation at break (EAB) of films were measured according to ASTM-D638-77 using INSTRON 4302 Machine Series IX with $100 \mathrm{~N}$ load cell, a velocity of $1.0 \mathrm{~mm} \mathrm{~s}-1$, with the distance between clamps was $50 \mathrm{~mm}$. Test samples were cut in dumb-bell shaped with $10 \mathrm{~mm}$ long and $3 \mathrm{~mm}$ width, flaring to $20 \times 10 \mathrm{~mm} 2$ grip areas on both ends.

\section{6) Solubility}

Film solubility was determined by cutting the films into strips of $1.5 \times 1.5 \mathrm{~cm}$ pieces and followed the method by Perez-Gago and Krochta [5].

\section{7) Water vapor permeability (WVP)}

WVP was determined using a modification of ASTM Method E 96 (2000) described by Pitak \& Rakshit [6].

\section{8) Statistical analysis}

The Excel (Microsoft Inc.) and Minitab 16 software (Minitab Inc.) were utilised to analyse data. The statistical analysis of the data was carried out by one-way (unstacked) analysis of the variance (ANOVA) and a Turkey test of multiple comparisons with a significance level of $5 \%$.

\section{RESULTS AND DISCUSSION}

\section{A. Thickness}

Generally, raising plasticizer concentration will increase the film thickness due to more free volume produced. However, the thickness of films plasticized with glycerol and sorbitol up to $50 \%$ concentration did not show significant increased (Table I). However, films added with PEG exhibited significant effect on thickness as films with 40 and $50 \%$ of this plasticizer had higher thickness $(\mathrm{P} \leq 0.05)$ compared to films with glycerol and sorbitol.

\section{TABLE I}

THICKNESS OF UNRIPE BANANA FILM INCORPORATED WITH DIFFERENT TYPE AND CONCENTRATION OF PLASTICIZER

\begin{tabular}{|l|l|}
\hline Concentrations (\%) & Thickness (mm) \\
\hline Glycerol & \\
10 & $0.11 \pm 0.01^{\mathrm{abA}}$ \\
20 & $0.11 \pm 0.01^{\mathrm{abB}}$ \\
30 & $0.10 \pm 0.01^{\mathrm{aB}}$ \\
40 & $0.12 \pm 0.01^{\mathrm{abB}}$ \\
50 & $0.11 \pm 0.01^{\mathrm{aB}}$ \\
Sorbitol & \\
10 & $0.11 \pm 0.02^{\mathrm{aA}}$ \\
20 & $0.13 \pm 0.02^{\mathrm{aA}}$ \\
\hline
\end{tabular}

\begin{tabular}{|l|l|}
\hline 30 & $0.11 \pm 0.01^{\mathrm{aAB}}$ \\
40 & $0.12 \pm 0.01^{\mathrm{aB}}$ \\
50 & $0.11 \pm 0.01^{\mathrm{aB}}$ \\
\hline PEG & \\
10 & $0.097 \pm 0.01^{\mathrm{bB}}$ \\
20 & $0.14 \pm 0.02^{\mathrm{aA}}$ \\
30 & $0.12 \pm 0.02^{\mathrm{aA}}$ \\
40 & $0.13 \pm 0.01^{\mathrm{aA}}$ \\
50 & $0.13 \pm 0.02^{\mathrm{aA}}$ \\
\hline
\end{tabular}

*Values are presented as mean $\pm \mathrm{SD}(\mathrm{n}=3)$

*Different superscript letters $(\bar{a}, \mathrm{~b}, \mathrm{c})$ indicate significant differences $(\mathrm{P} \leqslant 0.05)$ in the same column under the same type of plasticizer. Different superscript letters $(\mathrm{A}, \mathrm{B}, \mathrm{C})$ indicate significant differences $(\mathrm{P} \leqslant 0.05)$ in the same column under the same concentration.

TABLE II

COLOUR PROPERTIES OF UNRIPE BANANA FILM INCORPORATED WITH DIFFERENT TYPE AND CONCENTRATION OF PLASTICIZER

\begin{tabular}{|c|c|c|c|}
\hline $\begin{array}{c}\text { Concentrations } \\
(\%)\end{array}$ & $\mathbf{L}^{*}$ & $\mathbf{a}^{*}$ & $\mathbf{b}^{*}$ \\
\hline Glycerol & & & \\
10 & $79.83 \pm 1.41^{\mathrm{bB}}$ & $1.31 \pm 0.16^{\mathrm{bcAB}}$ & $2.94 \pm 0.31^{\mathrm{bC}}$ \\
20 & $80.52 \pm 2.02^{\mathrm{bA}}$ & $1.22 \pm 0.19^{\mathrm{bcB}}$ & $5.61 \pm 0.72^{\mathrm{aB}}$ \\
30 & $80.9 \pm 0.89^{\mathrm{bA}}$ & $1.58 \pm 0.07^{\mathrm{abB}}$ & $4.96 \pm 1.08^{\mathrm{aB}}$ \\
40 & $80.25 \pm 0.33^{\mathrm{bB}}$ & $1.02 \pm 0.07^{\mathrm{cC}}$ & $5.30 \pm 0.38^{\mathrm{aC}}$ \\
50 & $81.94 \pm 2.58^{\mathrm{aA}}$ & $1.62 \pm 0.05^{\mathrm{aA}}$ & $2.75 \pm 0.63^{\mathrm{bC}}$ \\
Sorbitol $_{10}$ & & & \\
20 & $77.05 \pm 0.50^{\mathrm{cC}}$ & $1.27 \pm 0.12^{\mathrm{bB}}$ & $3.97 \pm 0.53^{\mathrm{cC}}$ \\
30 & $80.64 \pm 0.87^{\mathrm{bA}}$ & $1.64 \pm 0.20^{\mathrm{aAB}}$ & $8.37 \pm 1.58^{\mathrm{aA}}$ \\
40 & $81.93 \pm 2.85^{\mathrm{aA}}$ & $1.67 \pm 0.11^{\mathrm{aA}}$ & $6.43 \pm 2.05^{\mathrm{bB}}$ \\
50 & $80.66 \pm 1.47^{\mathrm{bB}}$ & $1.65 \pm 0.07^{\mathrm{aA}}$ & $3.70 \pm 1.01^{\mathrm{cB}}$ \\
PEG & & & \\
10 & $81.86 \pm 1.73^{\mathrm{aA}}$ & $1.34 \pm 0.29^{\mathrm{cAB}}$ & $8.31 \pm 0.14^{\mathrm{bA}}$ \\
20 & $79.93 \pm 1.1^{\mathrm{bB}}$ & $1.46 \pm 0.12^{\mathrm{abA}}$ & $10.53 \pm 0.85^{\mathrm{aA}}$ \\
30 & $72.31 \pm 0.75^{\mathrm{cB}}$ & $1.73 \pm 0.12^{\mathrm{aA}}$ & $8.02 \pm 0.49^{\mathrm{bA}}$ \\
40 & $81.07 \pm 0.77^{\mathrm{aA}}$ & $1.54 \pm 0.12^{\mathrm{bB}}$ & $10.48 \pm 1.14^{\mathrm{aA}}$ \\
50 & $78.82 \pm 1.04^{\mathrm{bC}}$ & $1.50 \pm 0.18^{\mathrm{bAB}}$ & $8.62 \pm 0.40^{\mathrm{bA}}$ \\
\hline
\end{tabular}

*Values are presented as mean \pm SD $(n=3)$

* Different superscript letters $(\mathrm{a}, \mathrm{b}, \mathrm{c})$ indicate significant differences $(\mathrm{P} \leq 0.05)$ in the same column under the same type of plasticizer. Different superscript letters $(\mathrm{A}, \mathrm{B}, \mathrm{C})$ indicate significant differences $(\mathrm{P} \leq 0.05)$ in the same column under the same concentration.

\section{B. Colour Measurement}

Hunter L*(lightness), $\mathrm{a}^{*}$ (redness) and $\mathrm{b}^{*}$ (yellowness) colour values of banana films are shown in Table II. Results showed that the colour of banana films was not affected by the glycerol, regardless the concentration. However, films with $20 \%$ sorbitol and $30 \%$ PEG had significant $(\mathrm{P} \leq 0.05)$ effect on lightness.

\section{Mechanical Test}

The mechanical properties of banana films are shown in Table III. The test indicated that no significant $(\mathrm{P} \geq 0.05)$ effect on TS values observed for the films with glycerol and 
sorbitol, irrespective of the concentrations used. Similarly, no significant differences observed for elongation at break (EAB) and Young's modulus (YM) of films regardless the concentration used. No data was obtained for banana films with $10 \%$ glycerol and sorbitol due to the structure changes of the films that shrink and too brittle due to lack of plasticizers.

\section{Water Vapour Permeability (WVP)}

Fig. 1 shows the WVP of banana films with different plasticizers. Results indicated that increased the glycerol concentrations in banana films to $30 \%$ had increased the WVP of the films. In contrast, incorporation of sorbitol and PEG in banana films up to $40 \%$ concentrations had lowered the WVP values. Glycerol molecules have high capacity to interact with the polymer chain because of its small size thus enhanced its molecular mobility. Meanwhile, at $40 \%$ concentration of glycerol, the value of WVP decreased. However, at $50 \%$ concentration of plasticizers, the WVP became higher. In general, PEG had lower WVP at 30 and $40 \%$ concentrations.

TABLE III

MECHANICAL PROPERTIES OF UNRIPE BANANA FILM INCORPORATED WITH DIFFERENT TYPE AND CONCENTRATION OF PLASTICIZER

\begin{tabular}{|c|c|c|c|}
\hline $\begin{array}{c}\text { Concentrations } \\
(\%)\end{array}$ & $\begin{array}{c}\text { Tensile } \\
\text { strength } \\
(\mathbf{M P a})\end{array}$ & $\begin{array}{c}\text { Elongation } \\
\text { Modulus } \\
(\mathbf{M P a})\end{array}$ & $\begin{array}{c}\text { Elongation at } \\
\text { break (\%) }\end{array}$ \\
\hline $\begin{array}{c}\text { Glycerol } \\
10\end{array}$ & $\mathrm{ND}$ & $\mathrm{ND}$ & $\mathrm{ND}$ \\
20 & $7.32 \pm 1.372^{\mathrm{cA}}$ & $1.012 \pm 0.582^{\mathrm{bC}}$ & $100.60 \pm 19.3^{\mathrm{bA}}$ \\
30 & $11.24 \pm 4.67^{\mathrm{aA}}$ & $2.697 \pm 1.834^{\mathrm{aB}}$ & $142.60 \pm 92.45^{\mathrm{aA}}$ \\
40 & $8.11 \pm 4.384^{\mathrm{bA}}$ & $2.680 \pm 1.045^{\mathrm{aB}}$ & $61.58 \pm 73.33^{\mathrm{cB}}$ \\
50 & $6.88 \pm 1.163^{\mathrm{dA}}$ & $1.142 \pm 0.072^{\mathrm{bC}}$ & $86.07 \pm 48.80^{\mathrm{dA}}$ \\
Sorbitol & & & \\
10 & $N D$ & $\mathrm{ND}$ & $\mathrm{ND}$ \\
20 & $6.99 \pm 1.553^{\mathrm{aAB}}$ & $4.021 \pm 2.601^{\mathrm{bA}}$ & $88.61 \pm 61.78^{\mathrm{aA}}$ \\
30 & $4.73 \pm 2.478^{\mathrm{cB}}$ & $4.717 \pm 1.334^{\mathrm{aA}}$ & $33.78 \pm 22.82^{\mathrm{cC}}$ \\
40 & $6.01 \pm 4.597^{\mathrm{bB}}$ & $5.148 \pm 0.447^{\mathrm{aA}}$ & $37.68 \pm 32.71^{\mathrm{cC}}$ \\
50 & $7.04 \pm 2.372^{\mathrm{aA}}$ & $4.056 \pm 0.323^{\mathrm{bA}}$ & $62.09 \pm 14.79^{\mathrm{bB}}$ \\
PEG & & & \\
10 & $10.25 \pm 4.287^{\mathrm{aA}}$ & $4.299 \pm 0.315^{\mathrm{bA}}$ & $116.97 \pm 83.35^{\mathrm{bA}}$ \\
20 & $7.76 \pm 1.062^{\mathrm{bA}}$ & $4.030 \pm 0.973^{\mathrm{bA}}$ & $109.17 \pm 27.09^{\mathrm{cA}}$ \\
30 & $3.58 \pm 0.712^{\mathrm{cC}}$ & $6.146 \pm 2.941^{\mathrm{aA}}$ & $65.07 \pm 14.82^{\mathrm{dB}}$ \\
40 & $8.65 \pm 3.128^{\mathrm{bA}}$ & $2.328 \pm 0.783^{\mathrm{cB}}$ & $168.10 \pm 86.51^{\mathrm{aA}}$ \\
50 & $2.26 \pm 0.526^{\mathrm{cB}}$ & $2.160 \pm 1.281^{\mathrm{cB}}$ & $34.45 \pm 4.66^{\mathrm{eC}}$ \\
\hline
\end{tabular}

*Values are presented as mean+SD $(n=3)$

*Different superscript letters $(\mathrm{a}, \mathrm{b}, \mathrm{c})$ indicate significant differences $(\mathrm{P} \leq 0.05)$ in the same column under the same type of plasticizer. Different superscript letters $(A, B, C)$ indicate significant differences $(\mathrm{P} \leq 0.05)$ in the same column under the same concentration.

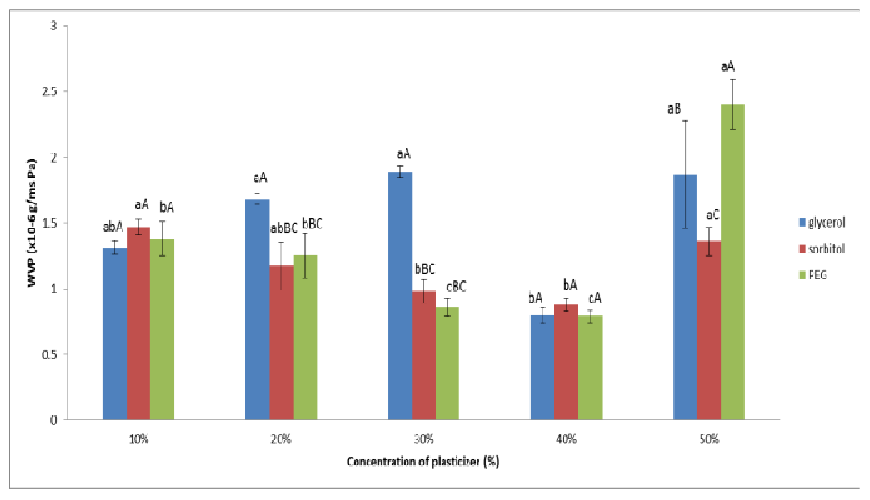

Fig. 1 Water vapour permeability of unripe banana film incorporated with different type and concentration of plasticizer

\section{E. Solubility}

Solubility values of banana films with different plasticizers are shown in Fig. 2 The solubility of banana films increased with the plasticizers concentrations. As these plasticizers have polar characteristics, the films can interact with water easliy. Therefore, increasing the concentration of plasticizers increased the solubility as more polar groups existed for water interaction. Banana films with glycerol had the lowest solubility values compared to sorbitol and PEG exept at $10 \%$ concentrations. The lower solubility obtained for films with glycerol is due to the small sizes of glycerol molecules that give high mobility and ability to occupy the free spaces in starch matrices, as explained by Sorthornvit et al. [7].

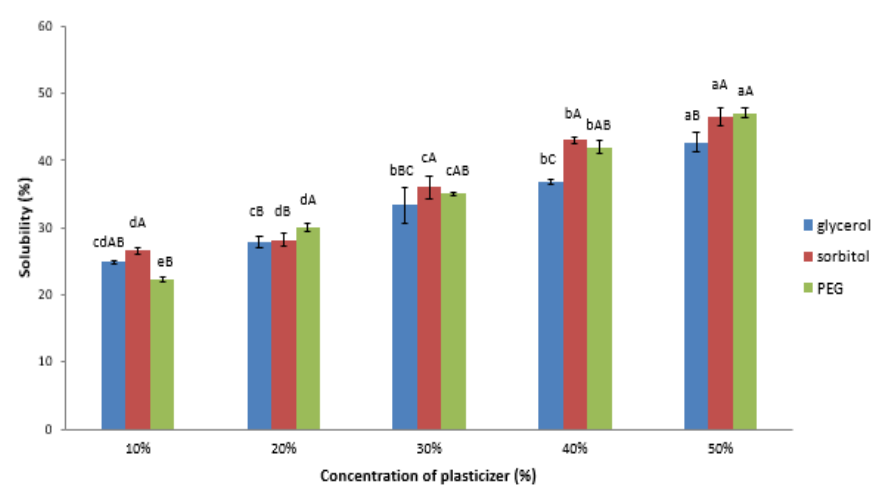

Fig. 2 Solubility of unripe banana film incorporated with different type and concentration of plasticizer

\section{CONCLUSIONS}

Physical properties of banana films with different plasticizers were determined. Concentrations and type of plasticizers used have influenced the mechanical properties of banana films. However, increasing the plasticizers concentration had increased the solubility values. Glycerol possesses the lowest solubility value compared to sorbitol and PEG, despite concentration used. However, further research is needed to establish and enhance the banana films properties. 


\section{ACKNOWLEDGMENT}

We would like to thank Universiti Putra Malaysia (UPM) for sponsoring this project under a grant of APIPM/2013/9424700.

\section{REFERENCES}

[1] D.W. Turner, "Bananas and plantains" pp. 45-77. In: Mitra SK. (ed.) Postharvest physiology and storage of tropical and subtropical fruits. CABI Publishing, UK, 2001.

[2] R. Sorthornvit, and J. M. Krochta, "Plasticizer effect on mechanical properties of Beta-lactoglobulin films," Journal of Food Engineering, 50, pp. 149-155, 2001.

[3] P. M. Kotecha, and B. B. Desai, "Banana" In D. K. Salunkhe, and S. S. Kadam (Eds.), Handbook of fruit sciene and technology:
Production, composition, storage and processing. pp. 67-90. New York: Marcel Dekker. 1995

[4] R. Sothornvit, and N. Pitak, "Oxygen permeability and mechanical properties of banana films", Food Research International, 40, pp. 365-370, 2007.

[5] M. B. Perez-Gago and J. M. Krochta, "Lipid particle size effect on water vapor permeability and mechanical properties of whey protein/beeswax emulsion films. J. of Agric. Food Chem., 49(2), pp. 996, 2001.

[6] N. Pitak and S. K. Rakshit. Physical and antimicrobial properties of banana flour/chitosan biodegradable and self-sealing films used for preserving Fresh-cut vegetables. LWT-Food Science and Technology 44(10), pp. 2310-2315, 2011.

[7] C. Tadini, and C. Ditchfield, Carbohidratos en Alimentos Regionales Iberoamericanos, pp. 429-455, 2006. 